\title{
PERCEPTION AND EXPECTATION ON THE "ALERT VILLAGE" PROGRAM AMONG HIGH RISK PREGNANT WOMEN IN LUMAJANG, EAST JAVA
}

\author{
Endah Suprihatin \\ Health Polytechnics, Ministry of Health, Surabaya
}

\begin{abstract}
BACKGROUND: The "Alert Village" is a government program that aims to help empower village communities to achieve optimal health. With this program village communities are expected to have high concern, responsibility, and responsiveness to local health problems. Village communities are expected to be aware and well-informed about their own health. They are expected to be alert and ready to respond correctly to health risk and hazard. They must have the ability and willingness to identify causes of health problem and improve their own health. This study aimed to document the perception and expectation among high risk pregnant women on the "Alert Village" program as indicated in Lumajang district, East Java
\end{abstract}

SUBJECT AND METHODS: This was a qualitative study carried out in Lumajang district, East Java. The primary informants were high risk pregnant women. The secondary informants included local communities, health personnels and maternal health programmers. The data were collected by in-depth interview, direct observation, and document review.

RESULTS: Most pregnant women perceived that the introduction of the "Alert Village" program had brought about improvement in the provision of women health care. The health personels monitored high risk pregnant women more intensely. The quality of the ante-natal care and delivery care was improved and they were more accessible to pregnant women. The communities had more power and control over their own resources. They collected fund from the community members to help support pregnant women to cover the costs associated with ante-natal and delivery care. Transportation showed improvement and it eased referal system. Some expectations are expressed to be realized: (1) Increased frequency of antenatal visits to high risk pregnant women; (2) Provision of concomitant health education at the point of care; (3) Provision of an aid program that supplies nutritious food supplement to high risk pregnant women.

CONCLUSION: The "Alert Village" has improved the quality and quantity of ante-natal and delivery care to high risk pregnant women. It empowers the communities to have control over their own health problems. Yet continuing actions need to be taken to maintain and improve these initiatives.

Keywords: "Alert Village program”, high risk pregnant women, antenatal care, delivery care 